\title{
CEROTUNGSTITE, A CERIAN ANALOGUE TO YTTROTUNGSTITE, FROM UGANDA
}

\author{
Th. G. Sahama ${ }^{1}$, Oleg v. Knorring ${ }^{2}$ and Martiti Lehtinen ${ }^{1}$ \\ 1 Dept. of Geology, University of Helsinki, Finland \\ 2 Dept. of Earth Sciences, Leeds University, U. K.
}

\begin{abstract}
This paper describes the mineral cerotungstite found as a secondary crystallization in some tungsten deposits in northern Rwanda and in the Kigezi District of south-western Uganda. Cerotungstite represents a cerian analogue to yttrotungstite known from the Kramat Pulai tin deposit in Malaysia. Therefore, some new data for the Kramat Pulai yttrotungstite are given for comparison.

Cerotungstite is associated with anthoinite and with an aluminian analogue to ferritungstite. It occurs as radiated groups of orange yellow bladed crystals with intimate twinning on (001). Single crystal X-ray data indicate the monoclinic space group $P 2_{1}$ or $P 2_{1} / \mathrm{m}$. Indexed powder pattern is given. The unit cell dimensions are $a_{0}=5.874 \AA, b_{0}=$ $8.700 \AA, c_{0}=7.070 \AA, \beta=105^{\circ} 27^{\prime}$. The chemical analysis reported yields the idealized formula $(\mathrm{RE}) \mathrm{W}_{2} \mathrm{O}_{6}(\mathrm{OH})_{3}$ with $Z=2$. The relative abundances of the rare earth elements were determined. Ce and $\mathrm{Nd}$ strongly predominate over Y.

The X-ray powder pattern and the single crystal data for the Kramat Pulai yttrotungstite are similar to those for the Uganda cerotungstite except that the unit cell deduced for yttrotungstite is slightly smaller: $\mathrm{a}_{0}=5.774 \AA, b_{0}=$ $8.643 \AA, c_{0}=6.957 \AA, \beta=104^{\circ} 47^{\prime}$. In conjunction with the previous chemical data available for the Kramat Pulai mineral, a new chemical analysis indicates the same formula as that given for cerotungstite, with the difference that $\mathrm{Y}$ predominates over the cerium earth elements.
\end{abstract}

\section{Introduction}

A secondary tungsten- and thorium-bearing mineral (thorotungstite) was described by Scrivenor and Shenton (1927) from the Kramat

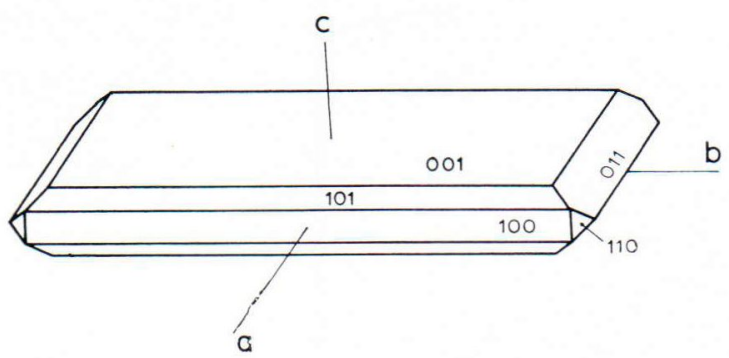

Fig. 1. Shape of a single cerotungstite crystal. Kirwa Mine, Kigezi, Uganda.
Pulai tin workings in Perak (Malaysia). Beard (1950) pointed out that the mineral actually represents a tungstite of yttrium and he renamed it yttrotungstite. The relative amounts of the rare earth elements in yttrotungstite were quantitatively given by Butler (1957) confirming the predominance of yttrium. Bradford (1961) published a new chemical analysis of the mineral reporting the absence of thorium.

Recently, Semenov et al. (1965) made a more detailed study of yttrotungstite from the original locality on a specimen obtained from Dr. Butler. These authors confirmed essentially the composition already summarized by Butler (op. cit.) and Bradford (op. cit.) and arrived at the ideal- 
ized formula $\mathrm{Y}_{2} \mathrm{~W}_{5} \mathrm{O}_{14}(\mathrm{OH})_{8}$ or possibly $\mathrm{YW}_{3} \mathrm{O}_{9}(\mathrm{OH})_{3}$. The DTA analysis revealed an endothermic reaction at $550^{\circ} \mathrm{C}$ which corresponds to a loss of $4.7 \%$ water (thermobalance). The infrared absorption spectrum indicates the presence of hydroxyl groups in the structure. The X-ray powder pattern (not indexed), density and optical properties were given.

The data made available by the authors mentioned indicate that the yttrotungstite represents a distinct species.

In some ferberite specimens from a few tungsten mines in northern Rwanda and in the Kigezi District of south-western Uganda a mineral was found which, under the binocular microscope, resembles the Kramat Pulai yttrotungstite. A subsequent comparison of the data for the Kigezi and the Kramat Pulai minerals with each other revealed the fact that these two minerals represent varieties of the same species. The only significant difference between the Kigezi and the Kramat Pulai minerals is in the relative amounts of the rare earth elements. The Kramat Pulai yttrotungstite shows a strong predominance of yttrium (Fig. 4 A). In the Kigezi mineral, on the other hand, the cerium earth elements, particularly $\mathrm{Ce}$ and $\mathrm{Nd}$, predominate and yttrium plays a minor role (Fig. 4 B). The Kigezi mineral cannot be called yttrotungstite. According to the rules proposed by Levinson (1966), the mineral should be called yttrotungstite-(Ce), but such a name seems undesirable. Therefore, the Kigezi mineral will be called cerotungstite in this paper in which the properties of the mineral are summarized.

\section{Morphology}

In the Kigezi ferberite specimens studied cerotungstite occurs preferably as radiated groups of shiny bladed crystals. The single crystals which can be detached from the radiated groups range up to some 100 microns in length and are not suited to accurate optical goniometry. The crystal faces summarized in Fig. 1

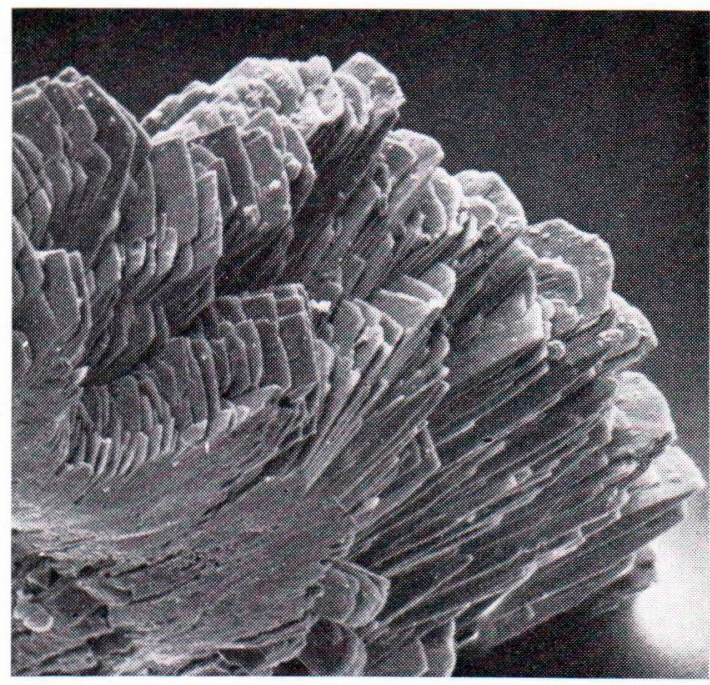

Fig. 2. Radiated crystal group of cerotungstite. Kirwa Mine, Kigezi, Uganda. Scanning electron microscope photograph. $120 \times$.

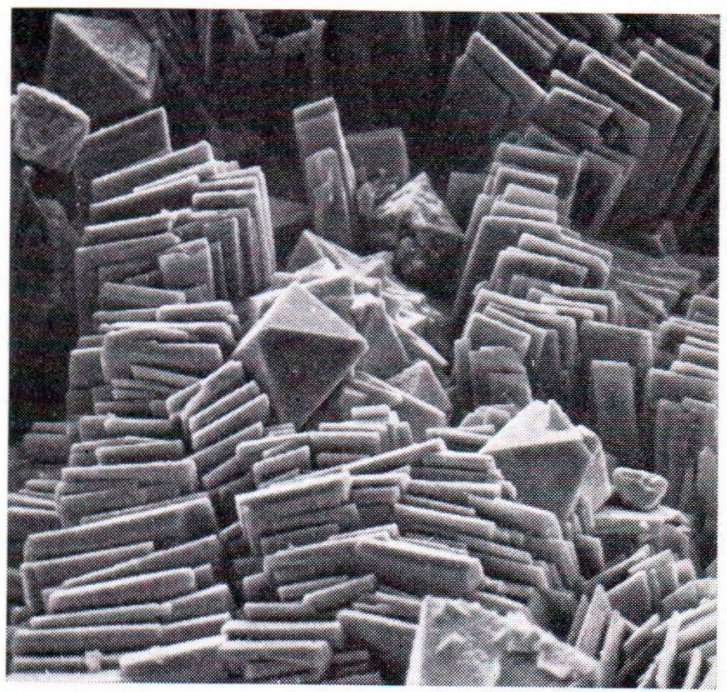

Fig. 3. Top view of a radiated crystal group of cerotungstite with some octahedra of aluminum analogue to ferritungstite. Kirwa Mine, Kigezi, Uganda. Scanning electron microscope photograph. $360 \times$.

could, however, be identified under the microscope (magnification 50-200 $\times$ ) by using a suitable spindle stage. The setting indicated is based on X-ray precession photographs. Fig. 2 presents a cross-section and Fig. 3 the top view of a radiated crystal group. The crystals exhibit a perfect cleavage parallel to (100). The $b$-axis 
precession photographs reveal an intimate twinning on (001).

According to the description by Scrivenor and Shenton (1927), the Kramat Pulai mineral shows a crystal habit essentially similar to that of Fig. 1 without, however, faces (100) and (110). In the specimens available to the authors the mineral occurs as radiated crystal groups in which the acicular to bladed single crystals are mostly poorly developed.

\section{Separation}

Crystals and crystal groups of cerotungstite displaying the morphology summarized above were found in several specimens mainly from the Kirwa and Nyamulilo Mines in Kigezi. The amount of the mineral available in most specimens was insufficient for chemical work. Among the ferberite specimens from Nyamulilo, however, one was found which contained a good size (1 $\mathrm{cm}$ diameter) cavity filled with cerotungstite. From this cavity the mineral was scraped off with a needle under the binocular microcope. The material was eluted in alcohol to remove the fine powder and the ferberite contamination was picked away. The sample thus obtained, which amounted to $300 \mathrm{mg}$, contained only a small amount of the aluminum analogue to ferritungstite (to be described on a later occasion) and no anthoinite or ferberite. This contamination causes the three strongest lines of the mineral to appear as barely visible peaks on the chart representing the cerotungstite powder pattern (not indicated in Table 1). This material was subjected to chemical analysis (Table 3 ).

There was ample material available from the Kramat Pulai mineral. The piece selected for chemical work was crushed and the sample to be analyzed was picked by hand under the binocular microscope. The material used was considered virtually pure.

\section{X-ray crystallography}

The sample of cerotungstite from the Nyamulilo Mine subjected to chemical analysis
(Table 3) was studied by X-ray powder pattern and by single crystal precession photographs. A small platy crystal was selected which exhibited homogeneous extinction under the polarizing microscope. The following preces-

TABLE 1

Powder pattern of cerotungstite compared with that of yttrotungstite

\begin{tabular}{|c|c|c|c|c|c|c|}
\hline \multicolumn{3}{|c|}{$\begin{array}{l}\text { Cerotungstite } \\
\text { Nyamulilo Mine, } \\
\text { Kigezi, Uganda }\end{array}$} & \multirow{2}{*}{$\begin{array}{c}\text { Probable } \\
\text { hkl }\end{array}$} & \multicolumn{3}{|c|}{$\begin{array}{l}\text { Yttrotungstite } \\
\text { Kramat Pulai, } \\
\text { Perak, Malaysia }\end{array}$} \\
\hline dmeas. & dealc. & I & & $\mathrm{d}_{\text {meas. }}$ & deale. & I \\
\hline 6.83 & 6.82 & 36 & 001 & 6.75 & 6.73 & 53 \\
\hline 5.67 & 5.66 & 3 & $10 \underline{0}$ & 5.60 & 5.58 & 15 \\
\hline 5.08 & 5.07 & 14 & $10 \overline{1}$ & 4.98 & 4. 96 & 66 \\
\hline 4.75 & 4.75 & 9 & 110 & 4.70 & 4.69 & 70 \\
\hline - & - & - & 020 & 4.33 & 4.32 & 10 \\
\hline 3.87 & 3.88 & 8 & 101 & 3.84 & 3.84 & 25 \\
\hline- & - & - & 021 & 3.64 & 3.64 & 7 \\
\hline- & - & - & 111 & 3.51 & 3.51 & 5 \\
\hline 3.405 & 3.407 & 100 & $00 \underline{2}$ & 3.363 & 3.363 & 100 \\
\hline 3.337 & 3.339 & 18 & $10 \overline{2}$ & 3.269 & 3.274 & 65 \\
\hline 3.301 & 3.301 & 9 & $12 \overline{1}$ & - & - & - \\
\hline 3.172 & 3.172 & 10 & 012 & 3.137 & 3.135 & 18 \\
\hline 3.117 & 3.117 & 14 & $11 \overline{2}$ & 3.068 & 3.062 & 30 \\
\hline 2.892 & 2.894 & 8 & 121 & 2.872 & 2.871 & 34 \\
\hline 2.831 & 2.831 & 10 & 200 & 2.792 & 2.791 & 36 \\
\hline 2.668 & 2.668 & 4 & 031 & 2.649 & 2.648 & 25 \\
\hline 2.627 & 2.627 & 17 & 102 & 2.601 & 2.602 & 35 \\
\hline- & - & - & $13 \underline{0}$ & 2.562 & 2.560 & 10 \\
\hline \multirow[t]{2}{*}{2.534} & 2.534 & 6 & $20 \overline{2}$ & - & - & - \\
\hline & $\int 2.517$ & & $\int 13 \overline{1}$ & 2.498 & 2.492 & 10 \\
\hline \multirow{2}{*}{$\begin{array}{r}2.516 \\
-\end{array}$} & $\{2.514$ & 8 & $\{112$ & 2.489 & 2.492 & 26 \\
\hline & - & - & 201 & 2.373 & 2.373 & 5 \\
\hline- & - & - & 131 & 2.300 & 2.305 & 5 \\
\hline 2.273 & 2.272 & 52 & 003 & 2.242 & 2.242 & 48 \\
\hline 2.196 & 2.198 & 2 & 013 & - & - & - \\
\hline 2.101 & 2.100 & 2 & 221 & 2.076 & 2.080 & 10 \\
\hline 2.052 & 2.052 & 5 & $23 \overline{1}$ & 2.025 & 2.026 & 32 \\
\hline \multirow[t]{2}{*}{2.012} & 2.014 & 9 & 023 & 1.994 & 1.990 & 18 \\
\hline & $\int 1.938$ & & $\int 202$ & & $\int 1.921$ & \\
\hline \multirow[t]{2}{*}{1.936} & $\{1.937$ & 5 & 103 & 1.922 & $\{1.918$ & 8 \\
\hline & $\int 1.892$ & & 212 & & $\int 1.875$ & \\
\hline 1.893 & $\{1.891$ & 5 & $\{113$ & 1.872 & $\{1.873$ & 9 \\
\hline \multirow[t]{2}{*}{1.848} & 1.848 & 2 & 231 & & $\int 1.832$ & \\
\hline & & & $22 \overline{3}\}$ & 1. 828 & $\{1.828$ & 14 \\
\hline 1.816 & 1.818 & 3 & $13 \overline{3}$ & 1.793 & 1.794 & 13 \\
\hline \multirow[t]{2}{*}{1.784} & 1.785 & 3 & $32 \overline{1}$ & - & - & - \\
\hline & - & 1 & 123 & 1.750 & 1.753 & 14 \\
\hline \multirow[t]{2}{*}{1.767} & 1.766 & 21 & $10 \overline{4}$ & 1.737 & 1.737 & 19 \\
\hline & $\int 1.731$ & & $\int 32 \underline{0}$ & & & \\
\hline 1.732 & $\{1.731$ & 3 & $\{11 \overline{4}$ & - & - & $\overline{10}$ \\
\hline 1.672 & 1.672 & 9 & 014 & 1.650 & 1.651 & 19 \\
\hline \multirow[t]{2}{*}{1.638} & 1.639 & 4 & $21 \overline{4}$ & - & - & - \\
\hline & 1.612 & & 232 & & 1.598 & \\
\hline \multirow[t]{2}{*}{1.610} & $\{1.611$ & 4 & 241 & 1.595 & $\{1.598$ & 12 \\
\hline & 1.611 & & 133 & & 1.597 & \\
\hline 1.580 & 1.582 & 3 & 330 & - & - & - \\
\hline 1.523 & 1.523 & 13 & 104 & 1.508 & 1.507 & 8 \\
\hline & - & -1 & $25 \overline{1}$ & 1.478 & 1.478 & 5 \\
\hline
\end{tabular}


sion photographs were taken: $a$-axis zero layer; $b$-axis zero, first and second layer. As was mentioned above, the crystal plate was found twinned. The symmetry is monoclinic and the only condition limiting possible reflection was found to be $k=2 \mathrm{n}$ for reflections of the type Ok0. The space group is thus $P 2_{1}$ or $P 2_{1} / \mathrm{m}$. The unit cell dimensions measured from the precession photographs and refined from the powder pattern are summarized in Table 2 . The indexed powder pattern is reproduced in Table 1. The agreement between the measured and the calculated $d$-values is excellent.

For comparison, a specimen of cerotungstite from the Kirwa Mine was subjected to X-ray study. The powder pattern photographed with the Weissenberg camera was found identical with that of the Nyamulilo mineral. The unit cell dimensions deduced from the $a$ - and $c$-axis precession photographs and the systematic extinctions detected agree with those of the Nyamulilo cerotungstite.

The Kramat Pulai yttrotungstite was also subjected to $\mathrm{X}$-ray study. The powder pattern, reproduced in Table 1 , agrees essentially with that given by Semenov et al. (1965) and compares well with that of the Nyamulilo cerotungstite. The unit cell dimensions of the Kramat Pulai mineral calculated from the powder pattern and summarized in Table 2 are somewhat smaller than those of the Nyamulilo mineral. The smaller unit cell of the Kramat Pulai yttrotungstite is in accordance with the smaller ionic radius of yttrium as compared with those of the cerian lanthanons. Precession photo-

TABLE 2

Unit cell dimensions of cerotungstite and yttrotungstite

\begin{tabular}{|c|c|c|}
\hline & $\begin{array}{l}\text { Cerotungstite. } \\
\text { Nyamulilo Mine, } \\
\text { Kigezi, Uganda }\end{array}$ & $\begin{array}{l}\text { Yttrotungstite. } \\
\text { Kramat Pulai, } \\
\text { Perak, Malaysia }\end{array}$ \\
\hline$a_{o} \ldots \ldots$ & $5.874 \pm 0.005 \AA$ & $5.774 \pm 0.005 \AA$ \\
\hline$b_{o} \ldots \ldots$ & $8.700 \quad »$ & $8.643 \quad 》$ \\
\hline$c_{o} \ldots \ldots \ldots$ & $7.070 \quad "$ & $6.957 \quad 》$ \\
\hline$\beta \ldots \cdots \cdots$ & $105^{\circ} 27^{\prime} \pm 05^{\prime}$ & $104^{\circ} 47^{\prime} \pm 10^{\prime}$ \\
\hline
\end{tabular}

graphs ( $b$-axis zero and first layer) of the Kramat Pulai mineral revealed a pattern similar to that of the Kigezi mineral.

\section{Optical properties}

Cerotungstite is orange yellow in a hand specimen and yellow with a slightly greenish tint under the microscope. No notable pleochroism could be detected.

The study of the optical orientation of the mineral is hampered by the intimate twinning. Mounted in Canada balsam or in immersion liquid the twinned crystals will mostly rest on (001). The mineral is very soft (Mohs' hardness around 1) and easily cleavable making ordinary thin sectioning impossible. Very thin crystal flakes resting on (001) reveal the optic axial plane to be parallel to the crystallographic $b$-axis with $\gamma \| b$. The crystal flakes were subsequently turned in to a vertical position. With respect to the trace of (001), the extinction on (100) and on (010) was found to be straight. On (010), the optical $\alpha$-direction is parallel to the trace of (001). The orientation of the $\alpha \beta$ section of the optical indicatrix on (010) can not, however, be deduced from the overall extinction on that section. Section (010) consists of two multiply twinned individuals which might show extinction positions slightly inclined in opposite directions. The overall extinction position or, more specifically, the position of the minimum light intensity might just represent the average of the extinction positions of the two individuals.

The optical orientation of cerotungstite may be summed up as follows: $\gamma \| b ; \beta$ subperpendicular to (001); $\alpha$ subparallel to $a$.

The refractive indices were determined using immersion liquids of high refraction. The following values were obtained:

$$
\begin{aligned}
& \alpha^{\prime}=1.89 \pm 0.01 \\
& \beta^{\prime}=1.95 \quad 》 \\
& \gamma=2.02 \quad \text { 》 }
\end{aligned}
$$


Here, $\alpha^{\prime}$ means perpendicular to $\gamma$ on $(001)$ and $\beta^{\prime}$ means perpendicular to (001). The retardation on (001) was measured with a Berek compensator. Subsequently, the crystal was turned into a vertical position and the thickness was measured with a micrometer eye piece. The birefringence was calculated to $\gamma-\alpha^{\prime}=0.13-0.14$. This value is in accordance with that calculable from the refractive indices given.

The refractive indices of the Kramat Pulai yttrotungstite as reported by Semenov et al. (1965; $\alpha=1.89, \beta=1.98, \gamma=2.02$ ) are virtually identical with those of the cerotungstite from Nyamulilo given above. The marked pleochroism of the yttrotungstite noticed by Semenov et al. could not be observed in the Kigezi cerotungstite.

\section{Chemical composition}

A new chemical analysis of the Kramat Pulai yttrotungstite was made by one of us (O.v.K.) with the following result: $\mathrm{WO}_{3} 71.64$, $\mathrm{Al}_{2} \mathrm{O}_{3} \quad 0.90, \mathrm{Fe}_{2} \mathrm{O}_{3}$ 0.09, $\mathrm{MgO} 0.37, \mathrm{CaO}$ 0.77, $\mathrm{RE}_{2} \mathrm{O}_{3} 20.58, \mathrm{SiO}_{2} 0.34, \mathrm{H}_{2} \mathrm{O}+4.88$, $\mathrm{H}_{2} \mathrm{O}-0.20$, total 99.77. A wet chemical analysis of the cerotungstite from Nyamulilo, Kigezi, was also made by one of us (O.v.K.).

TABLE 3

Chemical composition of cerotungstite and yttrotungstite

Calculated to $100 \%$.

\begin{tabular}{|c|c|c|c|c|}
\hline & \multicolumn{3}{|c|}{$\begin{array}{c}\text { Yttrotungstite } \\
\text { Kramat Pulai, Malaysia }\end{array}$} & \multirow{2}{*}{$\begin{array}{l}\text { Cerotungstite } \\
\text { Nyamulilo, Uganda } \\
\text { This paper }{ }^{3}\end{array}$} \\
\hline & $\begin{array}{c}\text { This paper } \\
\%\end{array}$ & $\begin{array}{c}\text { Semenov et.al. } \\
(1965)^{1} \\
\%\end{array}$ & $\begin{array}{c}\text { Bradford } \\
(1961)^{2} \\
\%\end{array}$ & \\
\hline $\mathrm{WO}_{3} \ldots \ldots \ldots \ldots \ldots \ldots \ldots$ & 72.20 & 71.79 & 71.69 & 70.68 \\
\hline $\mathrm{Al}_{2} \mathrm{O}_{3} \ldots \ldots \ldots \ldots \ldots \ldots$ & 0.91 & 1.73 & 0.87 & 0.05 \\
\hline $\mathrm{Fe}_{2} \mathrm{O}_{3} \ldots \ldots \ldots \ldots \ldots$ & 0.09 & 0.19 & 0.36 & 0.15 \\
\hline $\mathrm{MgO}^{2} \ldots \ldots \ldots \ldots \ldots \ldots$ & 0.37 & 0.22 & 0.17 & - \\
\hline $\mathrm{CaO} \ldots \ldots \ldots \ldots \ldots \ldots \ldots$ & 0.77 & 0.71 & 0.32 & 0.17 \\
\hline $\mathrm{RE}_{2} \mathrm{O}_{3} \ldots \ldots \ldots \ldots \ldots \ldots$ & 20.74 & 20.54 & 21.60 & 24.12 \\
\hline 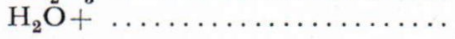 & 4.92 & 4.73 & 4.98 & 4.80 \\
\hline
\end{tabular}

1 Includes $0.08 \% \mathrm{ThO}_{2}$.

2 Includes $0.01 \% \mathrm{TiO}_{2}$.

3 Includes $0.03 \% \mathrm{Sc}_{2} \mathrm{O}_{3}$.

Unit cell content based on $\mathrm{O}+\mathrm{OH}=18$.

\begin{tabular}{|c|c|c|c|c|c|c|}
\hline $\mathbb{W}, \ldots \ldots \ldots \ldots \ldots \ldots \ldots \ldots \ldots \ldots \ldots \ldots$ & 3.74 & 3.727 & 3.72 & & 3.89 & \\
\hline 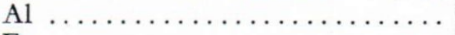 & 0.21 & 0.41 & 0.20 & 402 & 0.01 & 3.931 \\
\hline 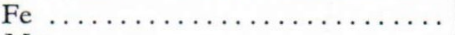 & $0.01\}$ & $0.03\}$ & 0.05 & 4.02 & 0.02 & \\
\hline 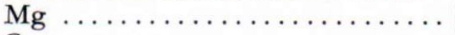 & 0.11 & 0.06 & 0.05 & & - & \\
\hline 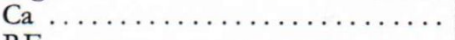 & 0.16 & $0.15\}$ & 0.07 & 2.02 & $0.04\}$ & 1.93 \\
\hline 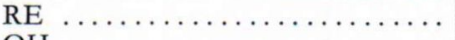 & $1.88\}$ & $1.85\}$ & 1.95 & 2.02 & 1.89 & 1.93 \\
\hline 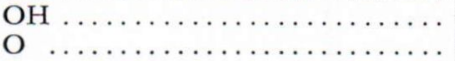 & $\left.\begin{array}{rl}6.56 \\
11.44\end{array}\right\}$ & $\left.\begin{array}{rl}6.29 \\
11.71\end{array}\right\} 18$ & $\begin{array}{r}6.65 \\
11.35\end{array}$ & 18 & $\begin{array}{r}6.80 \\
11.20\end{array}$ & 18 \\
\hline
\end{tabular}

1 Includes $0.01 \mathrm{Sc}$.

Atomic ratios of the rare earth elements in the Nyamulilo cerotungstite.

\begin{tabular}{|c|c|c|c|c|c|c|c|}
\hline $\mathrm{La}$ & 5.5 & $\mathrm{Pm}$ & - & $\mathrm{Tb}$ & 0.3 & $\mathrm{Tm}$ & 0.07 \\
\hline $\mathrm{Ce}$ & 41.8 & $\mathrm{Sm}$ & 6.8 & Dy & 1.6 & $\mathrm{Yb}$ & 0.3 \\
\hline $\operatorname{Pr}$ & 6.0 & $\mathrm{Eu}$ & 1.1 & Ho & 0.2 & $\mathrm{Lu}$ & 0.07 \\
\hline $\mathrm{Nc}$ & 24.8 & $\mathrm{Gd}$ & 3.4 & Er & 0.3 & Y & 7.7 \\
\hline
\end{tabular}


The $\mathrm{R}_{2} \mathrm{O}_{3}$ and the rare earth precipitates obtained from the cerotungstite were analyzed for RE using the XRF technique and solid-source spark mass spectrography. The result of this analysis is as follows: $\mathrm{WO}_{3} 71.17, \mathrm{Al}_{2} \mathrm{O}_{3}, 0.05$, $\mathrm{Fe}_{2} \mathrm{O}_{3} 0.15, \mathrm{CaO} 0.17, \mathrm{RE}_{2} \mathrm{O}_{3} 24.29, \mathrm{Sc}_{2} \mathrm{O}_{3} 0.03$, $\mathrm{H}_{2} \mathrm{O}+4.84, \mathrm{H}_{2} \mathrm{O}-0.27$, total 100.97. The high total probably results from the small amount of material available. These two analyses together with those previously published by Bradford (1961) and by Semenov et al. (1965) are compiled in Table 3 (calculated to $100 \%$ and neglecting $\mathrm{SiO}_{2}$ and $\mathrm{H}_{2} \mathrm{O}-$-).

Adopting the value for the density, viz. 5.82, given by Semenov et al. (op. cit.) for the Kramat Pulai mineral, the unit cell volume indicated in Table 2 and the composition of yttrotungstite summarized in Table 3 , the number of $\mathrm{O}+\mathrm{OH}$ in the unit cell was found to be 17.6. This figure is considered sufficiently close to 18 to justify the calculation of the unit cell contents from all analyses of Table 3 on the basis of $\mathrm{O}+\mathrm{OH}=18.00$. The result of the calculation approaches closely to the formula (RE,Ca) $(\mathrm{W}, \mathrm{Al}, \mathrm{Fe})_{4}(\mathrm{O}, \mathrm{OH})_{18}$ or idealized

$$
\text { (RE) } \mathrm{W}_{2} \mathrm{O}_{6}(\mathrm{OH})_{3}
$$

with $Z=2$. In this formula $\mathrm{RE}$ is replaced by $\mathrm{Ca}$ and $\mathrm{W}$ by $(\mathrm{Al}, \mathrm{Fe})$ to a minor extent and some $\mathrm{O}$ is replaced by $\mathrm{OH}$. This formula differs somewhat from that given by Semenov et al. (op. cit.).

The rare earth composition of the cerotungstite (given in Table 3) is diagrammatically compared with that of the yttrotungstite (using Butler's data) in Fig. 4.
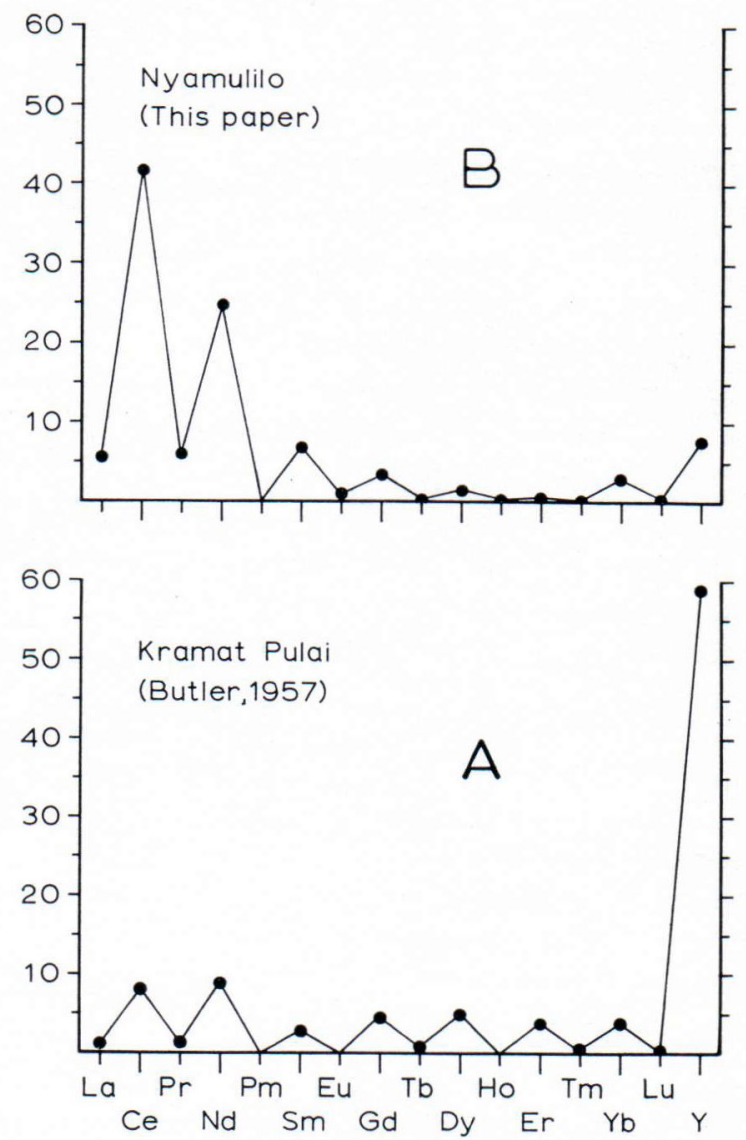

Fig. 4. Relative abundances of the rare earth elements in yttrotungstite from Kramat Pulai, Malaysia (A) and in cerotungstite from the Nyamulilo Mine, Kigezi, Uganda (B).

Acknowledgements - The authors are indebted to prof. Olavi Erämetsä and to Mr. K. Kukkasjärvi, of the Dept. of Chemistry, Technical University, Otaniemi, Finland, for determining the rare earth elements in cerotungstite.

The name cerotungstite has been approved by the Commission on New Minerals and Mineral Names of the International Mineralogical Association.

\section{REFERENCES}

BEARD, E. H. (1950) Thorotungstite - a misnomer. Colon. Geol. Min. Res., vol. 1, p. 50.

BRADFORD, E. F. (1961) The occurrence of tin and tungsten in Malaya. Proc. 9th Pacific Sci. Congr. (Bangkok meeting), sect. 12 , p. 378.

Butler, J. R. (1957) Rare earths in yttrotungstite. Geochim. et Cosmochim. Acta, vol. 12, p. 190.

Levinson, A. A. (1966) A system of nomenclature for rare-earth minerals. Amer. Miner., vol. 51, p. 152.
Scrivenor, J. B. and Shenton, J. C. (1927) Thorotungstite. A mineral containing tungsten and thorium from the Federated Malay States. Am. Jour. Sci., 5th series, vol. XIII, p. 487.

Semenov, E. J., Kataeva, Z. T. and Rudnitskaia, E. S. (1965) More facts about yttrotungstite. Dokl. Acad. Sci. U.S.S.R. Earth Sci. Sect., vol. 163, p. 103.

Manuscript received, April 13, 1970. 